\title{
'Waco' Pecan
}

\section{Tommy E. Thompson ${ }^{1}$ and L. J. Grauke ${ }^{2}$}

Pecan Genetics and Breeding Program, Agricultural Research Service, U. S. Department of Agriculture, 10200 FM50, Somerville, TX 77879

\section{Leonardo Lombardini ${ }^{3}$}

Department of Horticultural Sciences, Texas A\&MUniversity, College Station, Texas 77843-2133

\section{Additional index words. Carya illinoinensis, cultivar, breeding, genetics}

'Waco' is a new pecan [Carya illinoinensis (Wangenh.) K. Koch] cultivar released 11 Feb. 2005 by the U.S. Department of Agriculture (USDA), Agricultural Research Service(ARS), and the Agricultural Experiment Station of Texas. When compared to other protandrous cultivars, 'Waco' has excellent nut quality, and is suitable for planting in the western U.S pecan production area. 'Waco' pecans are large enough to be sold in-shell, or they can be shelled to produce a high proportion of intact halves and large pieces of very high quality.

\section{Origin}

USDA conducts the only national pecan breeding program. Crosses are made at Brownwood and College Station, Texas (Grauke and Thompson, 1996; Thompson and Grauke, 1991; Thompson and Young, 1985). Seedling clones are established on their own roots or budded to pollarded trees for the initial 10-year testing phase at College Station. Superior clones then enter the National Pecan Advanced Clone Testing System (NPACTS), where they are tested across the U.S. pecan belt. After several years, the best clones are given Native American tribe names and released to nurseries.

'Waco' is the 25th cultivar released by the USDAPecan Breeding Program in cooperation with various state agricultural experiment stations. All USDA cultivars (with the exception of 'Barton') have Native American tribe names. The 'Waco' tribe is one of the divisions of the Tawakoni, whose village stood until after 1830 on the site of the present city of Waco, Texas (Hodge, 1975). This name was chosen to associate the cultivar name with a geographic region where we think this new cultivar will perform well.

'Waco', tested as selection 75-5-6, is a progeny from a 1975 cross between the 'Cheyenne' and 'Sioux' cultivars made by E.J. Brown at the USDA Pecan Worksite, Brownwood, Texas. 'Cheyenne' is a USDA cultivar released in 1970 (Brooks and Olmo, 1970). It is known as the producer of the highest quality kernels of any cultivar. It is moderately resistant to pecan scab [Fusicladosporium effusum (Winter) Partridge

Received for publication 15 Mar. 2005. Accepted for publication 9 Aug. 2005.

${ }^{1}$ Research geneticist.

${ }^{2}$ Research horticulturist.

${ }^{3}$ Assistant professor. and Morgan-Jones], but very susceptible to the yellow aphid complex of pecan [damage caused by either or both the blackmargined aphid, Monellia caryella (Fitch), and the yellow pecan aphid, Monelliopsis pecanis (Bissell)]. 'Sioux' was released by the USDA in 1962 (Brooks and Olmo, 1962). It is also known for high nut quality and has moderate scab resistance. 'Sioux' is not as precocious as 'Cheyenne', and the nuts are slightly smaller (Grauke and Thompson, 1997). 'Waco' was released based upon the extensive testing in the replicated NPACTS tests at College Station, and Brownwood, Texas; upon the NPACTS test results obtained by Clay Zowarka of Pleasanton, Texas; and upon observations made by several other NPACTS testers across the U.S. pecan belt.

\section{Description}

Concerning the yield potential of 'Waco', it has precocity similar to 'Pawnee' and 'Desirable' (Table 1). Uniformity of production of 'Waco' across years is largely unknown. The NPACTS-B test at College Station, Texas (lat. $30^{\circ} 31^{\prime} \mathrm{N}$, long. $96^{\circ} 24^{\prime} \mathrm{W}$, elevation $67 \mathrm{~m}$ ) was essentially an unirrigated test since the orchard did not have an adequate water supply, espe- cially during high water requirement periods. Trees experienced a severe drought during the latter part of 1993, followed by an early devastating freeze of $-2{ }^{\circ} \mathrm{C}$. on 31 Oct. 1993. On that date, the trees were still foliated and fully susceptible to freezing. Carbohydrate reserves were also extremely low due to drought and heavy nut load, which could explain why freeze damage was severe on many trees of other clones. Although limbs of 'Waco' did not show any apparent damage, it is possible that the freeze was one reason why all trees in the test produced almost no crop in 1994. We do know that throughout this test period, 'Waco' excelled in producing a large quantity of quality nuts, even considering these environmental challenges.

'Waco' does not seem to overbear, based upon older trees under test. When fruits per cluster and percent of terminals with clusters is compared to 'Pawnee' and 'Stuart', 'Waco' appears to be intermediate in number of fruits per cluster, and to have fewer terminals with clusters than either of these comparison cultivars (Table 2). How these two measurements affect uniformity of production from year to year and nut quality is largely unknown.

'Waco' produces a large nut of exceptional quality (Fig. 1 and Table 3). Nut shape is elliptic with an obtuse apex, a somewhat acuminate (pointed) base and is laterally compressed in cross section. Average nut weight for 'Waco' is about $8.6 \mathrm{~g}$ but many years the nut weight greatly exceeds this value. Nuts have about $56 \%$ kernel, intermediate between 'Pawnee' and 'Desirable'. Kernels are cream to golden in color, and have wide, non-trapping dorsal grooves and rounded dorsal ridges. The basal cleft of 'Waco' is almost absent, comparable to that of the 'Sioux' parent. Nuts shell out easily into full halves and are very attractive. 'Waco' was compared to seven cultivars and 52 advanced USDA selections in aUSDA shelling

Table 1. Nut yield (kg/tree) of the 'Waco' pecan compared to other cultivars grown in the National Pecan Advanced Clone Testing System in College Station, Texas. Yield differences are nonsignificant.

\begin{tabular}{lcccccc}
\hline & \multicolumn{5}{c}{ Year } \\
\cline { 2 - 7 } Cultivar & 1989 & 1990 & 1991 & 1992 & 1993 & Total \\
\hline Waco & $0.2^{z}$ & 0.2 & 0.3 & 0.5 & 7.2 & 8.3 \\
Pawnee & 0.0 & 0.2 & 0.2 & 0.2 & 8.5 & 9.1 \\
Desirable & 0.0 & 0.3 & 1.3 & 1.5 & 4.7 & 7.8 \\
Stuart & 0.1 & 0.1 & 0.2 & 0.3 & 3.3 & 4.0 \\
\hline
\end{tabular}

${ }^{\mathrm{z}}$ Means of five single-tree replications, with clones grafted on established open-pollinated rootstocks in April 1986.

Table 2. National Pecan Advanced Clone Testing System data from College Station, Texas comparing the 'Waco' pecan to other cultivars for tree characteristics.

\begin{tabular}{lccrr}
\hline & \multicolumn{3}{c}{ Cultivar } \\
\cline { 2 - 4 } Characteristic $^{\mathrm{z}}$ & Waco & Pawnee & Desirable & Stuart \\
\hline Budbreak & $2.6 \mathrm{a}^{\mathrm{y}}$ & $1.7 \mathrm{a}$ & $2.2 \mathrm{a}$ & $1.0 \mathrm{~b}$ \\
Leaf scab & $2.8 \mathrm{a}$ & $1.9 \mathrm{~b}$ & $1.9 \mathrm{~b}$ & $1.6 \mathrm{c}$ \\
Nut scab & $1.8 \mathrm{a}$ & $1.5 \mathrm{~b}$ & $1.9 \mathrm{a}$ & $1.2 \mathrm{~b}$ \\
Blackmargined aphids & $0.8 \mathrm{a}$ & $0.2 \mathrm{c}$ & $0.3 \mathrm{c}$ & $0.5 \mathrm{~b}$ \\
TCA $\left(\mathrm{dm}^{2}\right)$ & $4.1^{\mathrm{NS}}$ & $3.3^{\mathrm{NS}}$ & $3.4^{\mathrm{NS}}$ & $4.3^{\mathrm{NS}}$ \\
Fruit per cluster & $2.6 \mathrm{~b}$ & $3.4 \mathrm{a}$ & $2.3 \mathrm{~b}$ & $2.1 \mathrm{c}$ \\
Terminals with clusters $(\%)$ & $11.9 \mathrm{c}$ & $28.3 \mathrm{a}$ & $30.0 \mathrm{a}$ & $19.1 \mathrm{~b}$ \\
\hline
\end{tabular}

${ }^{2}$ Budbreak ratings (1989) according to a 1 to 5 scale, with $1=$ dormant and $5=$ leaf expansion. Clone with smallest number is latest. Leaf and nut scab ratings 1 to $5,1=$ most resistant (Hunter and Roberts, 1978). Mean number of blackmargined aphids on leaflets 4 and 5 (Thompson and Grauke, 1998). TCA = trunk cross-sectional area recorded 14 Mar. 1996. Fruit per cluster and terminals with clusters are means across 7 years (1989-95).

${ }^{y}$ Means in rows with no common letters are different according to Duncan's multiple range test $(P<0.05)$. 


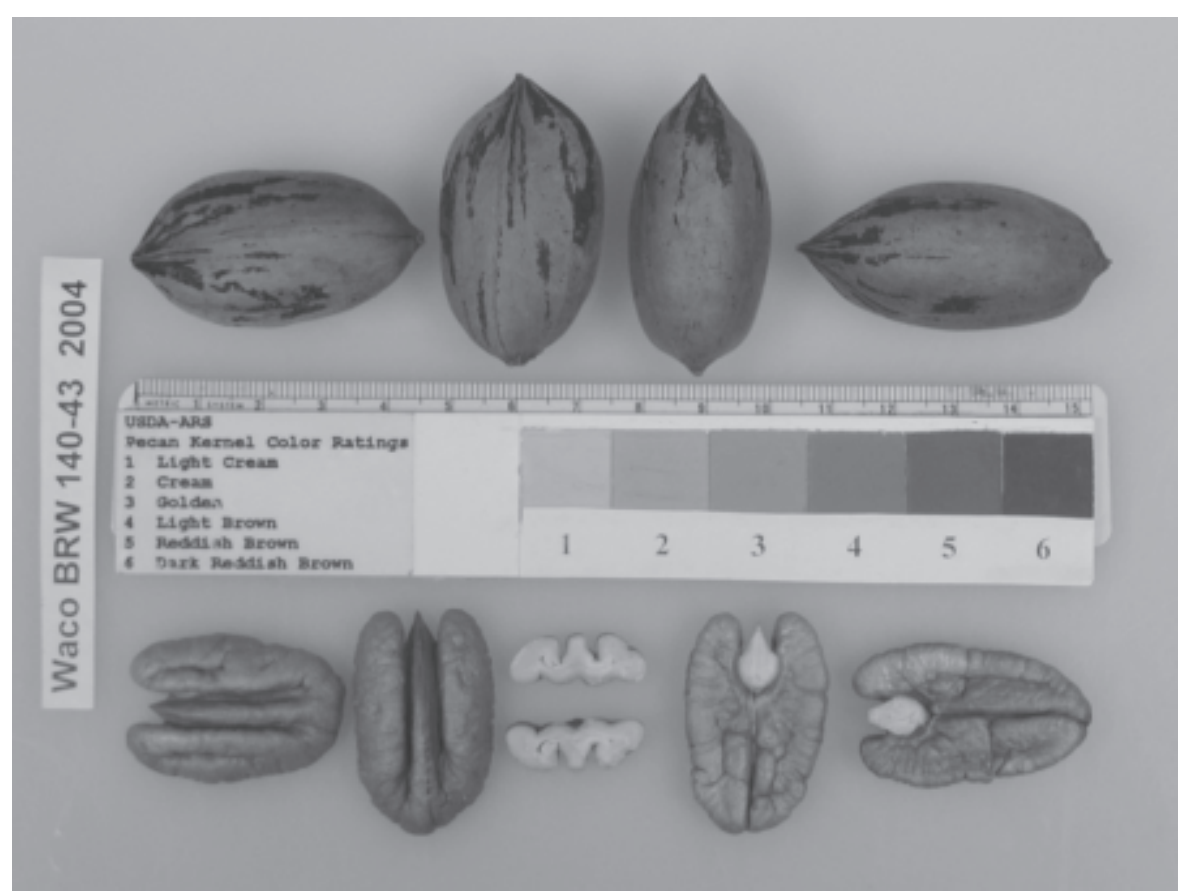

Fig. 1. Nuts and kernels of the 'Waco' pecan. Scale is in cm.

Table 3. National Pecan Advanced Clone Testing System data from College Station, Texas, comparing 'Waco' to other cultivars for nut characteristics. Each mean is the average for 3 years and 5 replications of 10 nut samples.

\begin{tabular}{lrrrr}
\hline & \multicolumn{4}{c}{ Cultivar } \\
\cline { 2 - 5 } Characteristic & Waco & Pawnee & Desirable & Stuart \\
\hline Nut weight (g) & 8.6 & 8.5 & 9.1 & 8.3 \\
Kernel (\%) & 56.2 & 59.3 & 54.2 & 48.4 \\
Kernel color $^{2}$ & 2.8 & 2.5 & 3.1 & 3.2 \\
\hline
\end{tabular}

${ }^{2}$ Kernel color is on a 1 to 10 scale with $1=$ the lightest (most desirable) color.

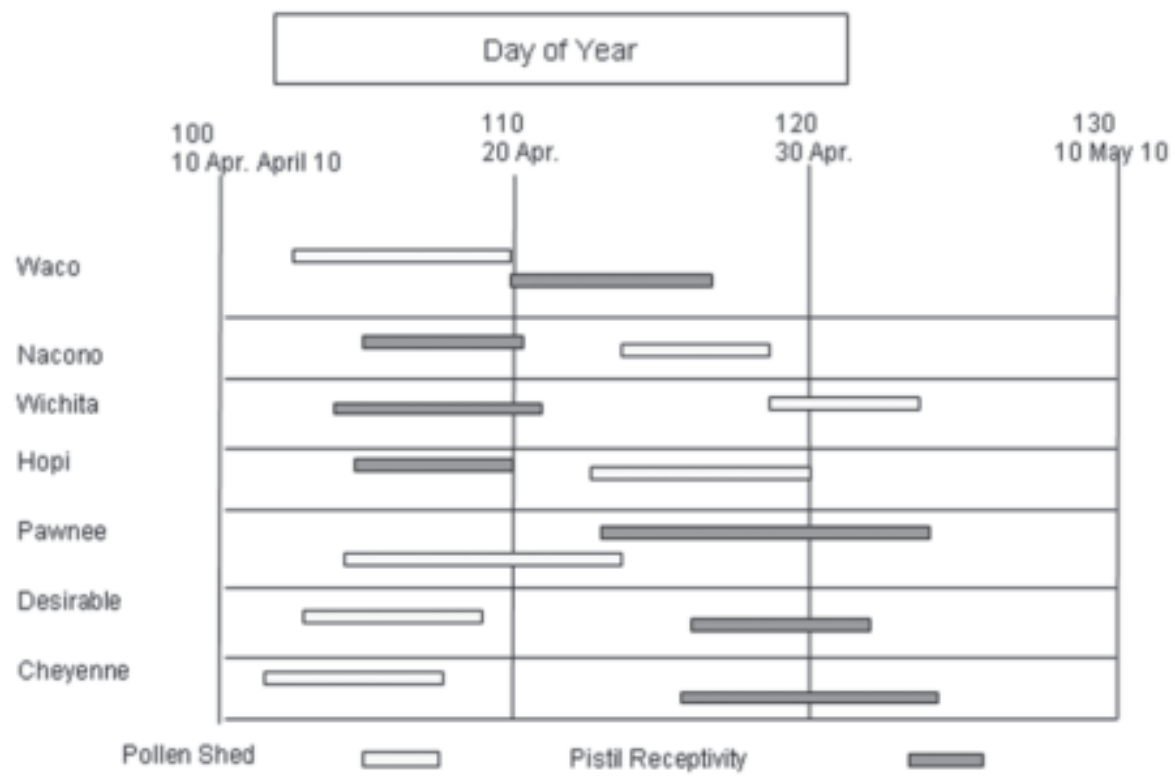

Fig. 2. Pollen shed and pistil receptivity for 'Waco' pecan and check cultivars at College Station, Texas, in 1999.

test in 2001 (Thompson and Grauke, 2003). On a 1 to 5 visual rating scale, the shelled kernels of 'Waco' were given the highest rating of 1 . Also, the shelled sample of 'Waco' kernels required less time to hand clean than any comparison cultivar nut sample, even 'Cheyenne'.

'Waco' trees are vigorous, with a branched is high, with excellent foliage distribution within the canopy.

Bud growth commences shortly before 'Desirable' in the spring (Table 2). Trees are protandrous (Fig. 2), with early to mid-season pollen shed and mid-season pistil receptivity (similar to 'Caddo' and 'Cheyenne'). 'Waco' should be a good pollenizer for, and be well pollenized by 'Wichita', 'Choctaw', 'Hopi', and 'Kanza'. Time of nut maturity is 11 to 21 Oct. in College Station, Texas which can be considered midseason, or about eight days before 'Desirable'. 'Waco' is more susceptible to pecan scab than 'Desirable' and some other common cultivars. Its scab resistance does exceed 'Western' and 'Wichita'. It is not recommended for East Texas or the Southeastern U.S.

'Waco' has medium to high susceptibility to blackmargined aphids (Table 2) (Thompson and Grauke, 1998). Since susceptibility to one species of aphids in pecan seems to indicate susceptibility to another species (Kaakeh and Dutcher, 1994), growers should monitor black aphid susceptibility in this new cultivar.

\section{Availability}

Budwood and graftwood will be supplied in 2005 only to nurseries. Requests should be directed to the senior author. The USDA does not have trees for distribution. Some budded or grafted trees should be available from nurseries for planting in early 2006.

\section{Literature Cited}

Brooks, R.M. and H.P. Olmo. 1962. Register of new fruit and nut varieties. List 17. Proc. Amer. Soc. Hort. Sci. 81:568-600.

Brooks, R.M. and H.P. Olmo. 1970 Register of new fruit and nut varieties. List 25. HortScience 5:383-390.

Grauke, L.J. and T.E. Thompson. 1996. Pecans and hickories, p. 185-239. In: J.A. Janick, and J.N. Moore (eds.). Fruit breeding. vol. 3. Nuts. Wiley and Sons, Inc., New York.

Grauke, LJ. and T.E. Thompson. 1997. Pecan, p. 544-562. In: The Brooks and Olmo register of fruit and nut varieties. 3rd ed. Amer. Soc. Hort. Sci. Alex., Va.

Hodge, F.B. 1975. Handbook of American Indians north of Mexico. Rowman and Littlefield. Totowa, N.J.

Hunter, R.E. and D.D. Roberts. 1978. A disease grading system for pecan scab. Pecan Qrtly. 12:3-6.

Kaakeh, W. and D. Dutcher. 1994. Probing behavior and density of Monelliopsis pecanis, Monellia caryella, and Melanocallis caryaefoliae (Homoptera: Aphididae) on pecan cultivars. J. Econ. Entomol. 87:951-956.

Thompson, T.E. and L.J. Grauke. 1991. Pecans and other hickories (Carya), p. 839-904. In: J.N. Moore and J.R. Ballington (eds.). Genetic resources of temperate fruit and nut crops. Intl. Soc. Hort. Sci., Wageningen, Netherlands.

Thompson, T.E. and L.J. Grauke. 1998. Field resistance to yellow aphids in pecan. J. Amer. Soc. Hort. Sci. 123:85-90.

Thompson, T.E. and L.J. Grauke. 2003. Pecan nut and kernel traits are related to shelling efficiency. HortScience 38:586-590.

Thompson, T.E. and E.F. Young, Jr. 1985. Pecan cultivars: Past and present. Texas Pecan Growers Assn., College Station. 